\title{
ROLE OF DEPOSIT POLICY FOR UKRAINIAN BANKING INSTITUTIONS
}

\author{
Nadezhda BOVA ${ }^{1}$, \\ Taras Shevchenko National University of Kiev, Ukraine
}

\begin{abstract}
The purpose of the paper is to define and demonstrate the role of deposit policy for banking institutions, summarize and highlight the problems and its solutions in deposit policy of Ukraine that provides economic downturn and recovery. Appropriate selection and implementation of the deposit policy objectives, its operational structure and tools determines the degree of development of financial inclusion, which generate developed financial market, ensures public confidence to the deposit services, and increases the level of savings that positively affects the banking system financial stability and economy in the country in whole. It is because of availability and security deposit services, commercial banks of Ukraine have the opportunity to increase its resource base due to savings of the population. Methodology. The paper is based on a synthesis of data to explore the bank deposit policy situation. The paper considers the scientific and theoretical approaches for the developing the deposit policy management. It contains the analysis of the dynamics and current situation and conditions of the resource potential of banking institutions in Ukraine. Results of the article shows direct dependency between savings, consumption and deposit policy, therefore every banking institution includes the mechanism of banking management of the development and implementation of deposit policy. Also, this management defines the deposit policy directions according to the conditions of bank resources mobilization and its applying in active operations. The obtained results confirm that the term "deposit policy" is too complex, but it is investigated in interaction with banking activity. It is explained how deposit policy influences banking system and has impact on economic growth in general. Practical implications. The research creates methodological approaches to the measurement of effectiveness of deposit policy. Also, it studies the existing ones. It provides the possibility to define which of the approaches works in non-stable economic situation and which ones not. The paper has the aim to assess the deposit policy opportunities in balancing and ensuring financial stability of the banking system of Ukraine in the period of economic growth and during the financial instability. Value/originality. Despite of the presence of significant scientific results in this field, deposit policy, today there is no established scientific literature and a comprehensive vision regarding the necessary focus and exposure mechanisms of deposit policy for the banking system. It determines the need to formalize the conceptual framework and the necessary conditions for a financial inclusiveness, deepening scientific and methodological basis of research deposit policy. This article provides the author's view on the important role of deposit policy for banking institutions and national economy in general.
\end{abstract}

Key words: deposit policy, savings, banking institutions, bank resources mobilization, banking management, bank resources.

JEL Classification: G21, E58, G29

\section{Introduction}

One of the main functions of the banking system is the rational allocation of financial resources by the accumulation of temporarily free funds of population and economic entities, and its focus on the credit and investment process. Reducing investments in the development of the domestic economy leads to enhance the role of accumulation and use of internal resources for restoring economic stability. Without sufficient resource base banking institutions are not able to carry out the current credit needs of businesses and individuals in the right amount. Also, there is no

Corresponding author

${ }^{1}$ Banking Department, Taras Shevchenko National University of Kiev.

E-mail: nadibova@gmail.com possibility to complete global investment projects. The sufficient condition for succeeding in these aims is to involve resources, especially, deposits. Bank institutions serve an important function by transforming deposits into real capital to provide additional resources for economic needs. Therefore, ensuring stable and effective development of the banking system, including resource optimization the capacity of the bank and minimizing the consequences of financial instability should be one of the main areas of banking activity. The abovementioned shows that ensuring stability and reliable functioning of banks in our country, 
scientifically substantiated formation convertible banking policy plays an important role, the main element of which is the deposit policy.

Deposit policy is the basis of the banking management. And its parameters determine the resource base and further bank activity. This is confirmed by the fact that the bulk of bank resources are created in the process of conducting deposit operations, efficiency and accuracy of the organization impacts on the stability of the banking institution ultimately.

\section{Deposit policy: role and functions}

Deposit policy is a complex economic phenomenon. Its essence is seen in a broad and a narrow sense. In broad terms, the bank's deposit policy is considered as the strategy and tactics of the bank in carrying out activities to attract deposit resources, as well as the organization and management of deposit process. In narrow sense deposit policy refers to the strategy and tactics of the bank in order to ensure its liquidity by deposit process.

Deposit policy is the base of the overall strategy of bank's activities to attract resources. Banking strategy and tactics are closely related, as tactics is the implementation of the strategy of banking institution. Therefore, the optimal combination of these two approaches enables banks to fulfill their main interest in the business world, which is intended to profitability and growth. But the deposit strategy and tactics are closely linked, in accordance with the same internal logic, which it incorporates such fundamental concept for the banking activity, as a deposit product, deposit, deposit service and deposit operation, that provides resource base of banking institution.

Another approach to define the term "deposit policy" is to consider its levels. Deposit policy functions at state and bank levels. Deposit policy at the state level is a set of measures and instruments to regulate the banks' activities. The state level is regulated by the central bank, the National bank of Ukraine, and it provides the rules of the formation of deposits for commercial and saving banking institutions, also for nonbanking financial organizations. Deposit policy at the bank level is a set of instruments that are used by banking institution to involve more resources to provide its activity.

When the policy of the central bank is strict, the deposit policy has the character of conservatism as it is strong regulated. The opposite situation is when the deposit policy is liberal. But in practical banking activity presents the combination of the both types of deposit policy.

So, it can be concluded that the deposit bank policy should be understood as a system of administrative decisions, a program of action, or the document containing the activities of the bank in the area of deposit operations.

Functions of deposit policy describe its role for any banking institution. The main function is the optimization of resource potential of bank. Also, deposit policy has such functions as:

- planning;

- programming;

- forecasting;
- motivating;

- commercial;

- control.

Every function of deposit policy has the aim to provide its principles:

- flexibility of deposit policy;

- documentarily registered deposit operations;

- rational management passive operations;

- high technologies in resource operations;

- active marketing and customer focus;

- rational resource policy;

- adequacy of deposit policy to demand on financial services (Dziubliuk, O., 2008).

The role of deposit policy is that it defines the priorities of development and improvement of banking activities, aimed to mobilize financial resources, improvement of the resource base formation and increasing competitiveness.

The author offers to pay attention to new principle, according to the research, that deposit policy has the principle of availability. This principle is about security of bank deposit portfolio and target use of funds performing property rights of depositors. Deposit policy should provide positive reputation and trust.

To conclude, there is direct dependence between depositors' savings, deposit policy functions and principles, banking activity and its rating.

\section{Deposit policy and factors of influence}

It is important to make deposit policy safe. It means deposit policy should create not risky financial services investments by subjects of the financial services market.

Many factors impacts on deposit policy. They could be divided into internal and external ones.

The external factors are defined as:

- the size of the discount rate of the central bank;

- banks' reserve requirements;

- inflation;

- inflation expectations of the population;

- dynamics of population incomes;

- the state of the monetary market;

- the state of the financial market;

- the political situation in the country;

- the economic situation;

- risks;

- demand on banking services;

- level of banking competition;

- regional specification;

- legislation (Fursova, V., 2011).

Globalization processes made domestic banks increasingly mobilize resources by borrowing on the international capital markets in the form of loans and foreign investments. However, today, when international banks reduced lending Ukrainian banks, the value of deposit resources despite becomes higher because of the lack of resources in the domestic banking market. So that banking institutions are forced to attract resources with various kinds of deposit operations. In such circumstances, 
banks should pay attention to the significant number of factors in the formation deposit policy objectives.

It is known that on the amount of borrowed funds has impact not only the general state of the economy of the country, but even a region, in which banking institution conducts its operations. It applies to external risks. They are not associated with of banking activity or its customers. It is obvious that in an unstable economic, the banking system development must be stable, despite the fact that it faces with all the consequences of inflation, crisis, problem payments, budget deficit, decline in GDP and so on (Barr, Nicholas, 2001).

The internal factors are:

- profitability;

- liquidity;

- reliability of bank institution;

- deposit interest rates;

- range of bank services;

- versatility of banking deposit products;

- marketing policy of the bank;

- development of banking technologies;

- stability of deposits;

- price policy of banking institution;

- bank customers;

- staff qualifications;

- experience;

- expenditure on deposit policy (Fursova, V., 2011).

Deposit policy of banking institution should be formed considering previously mentioned internal and external factors. Thus, the activities of bank management can improve the quality of deposit services and attract more resources.

Practical banking activity, according to our research, shows that internal factors of influence on deposit policy could be divided into several groups, they are:

- financial stability and statistics;

- staff preparation and qualification;

- image banking institution on the market of deposit services;

- quality and sales policy of deposit policy;

- organizational structure of banking institution.

To sum up, the author offers new groups of internal factors that are under banking management control and they allow any bank to be competitive and to provide deposit services better. The external factors should be considered as political, economic, technical and social ones, they are out of banking management control. But banking institution management is to monitor trends and to have flexible deposit policy. These groups of factors give opportunity to work out methodological approaches for organization, estimation, planning, forecasting and regulation of bank activity.

\section{Survey methodology}

In the paper are used logical and statistical methods, mathematically-economics approaches. It was analyzed the deposit policy at 5 competitive banks that have not less than 1 billion UAH deposits in their deposit portfolio according such parameters as payment of interest on deposits, the possibility of early withdrawal or recharge, investment terms, rate in UAH, rate in USD, bank's part in the market of retail deposits. We took the analytics from the National bank of Ukraine data base for the last periods and the customers' information from the website main pages of the analyzed banks. The author paid attention which principles are completed in the banks' activity and what conditions the banks use to attract new depositors and to keep the old ones. In Ukraine, we have the tendencies for declining the banks "deposit billionaires". The reasons why many of domestic financial institutions continue to decline are rather predictable. First of all it is massive outflow of deposits, the insolvency of many banks raising standards of the National bank of Ukraine, the total lack of confidence in the banking system, both from the public and from business.

\section{Findings}

The above confirms that the quality of the borrowed funds is determined by the level of bank deposit policy that is the set of its approach to risk management liabilities, the principles of formation of the resource base, effective communication between divisions of the bank and the distribution between them the duties related to the process of formation of resources, composition and quality of the portfolio of resources, providing high-quality documentary deposit policy.

Since 2008 till 2013 the share of banks' capital was gradually increasing in total liabilities slightly from $11.61 \%$ to $15.07 \%$. It shows a certain increase in equity capital of Ukrainian banks, since an increase in the proportion of capital occurred simultaneously with the increase in liabilities to $599,396 \mathrm{mln}$. UAH up to $1,278,095 \mathrm{mln}$. UAH at the beginning of 2014. At the same time, the share of bank liabilities in total liabilities decreased. But it should be noted that the proportion of individuals' funds in the total liabilities and the liabilities of the banks from 2008 to 2011 decreased, while from 2011 to 2015 grew. So, at the beginning of 2015 , the proportion of individuals in banks' liabilities amounted to almost $40 \%$.

Some researchers distinguish certain stages, during which the change in the role and value of household savings as a source of the resource potential of domestic banks.

Stage 1: forming a substantial public confidence in banks and the conversion of deposits of individuals on one of the main sources of the resource potential of the domestic banking sector, this lasted from 2002 till 2005. This stage was characterized by relative stability in the foreign exchange and financial markets during this period, banks offer the population quite attractive conditions for deposit programs. As a result, at the end of 2005 the resource potential of domestic banks consisted of people's savings for almost $35.0 \%$.

Stage 2: savings of the population cease to be the main source of the resource base of domestic banks as their share in bank resources is systematically reduced. This period started in 2006 and lasted till 2008. In 2006 it was formed $32.0 \%$ of the total resources of the banking sector of Ukraine due to the savings of the population, and at the beginning of 2008 this figure felt to $23.0 \%$. It was caused by world financial crisis and exchange instability. 
Stage 3: from 2008 till 2010 recovering period after financial stresses. The moratorium on faster and earlier withdrawal of deposits slightly decreased outflow of depositors' funds from the banking system, but at the same time, the negative impact on public confidence in the latter. The National bank of Ukraine undertook all possible measures to make recovery of the banking system.

Stage 4: restore confidence to the banking system of Ukraine and the growing role of savings as the main source of formation of the resource potential of the banks. This stage started in 2010 and lasted till 2014. This situation can be explained mainly by the lack of alternative sources in Ukraine where the citizens can invest. Lack of development of the stock market in Ukraine makes the bank deposits almost the only source of public investment.

Since 2014 economic, political and military situations changed a lot. So now we see the devaluation, bankruptcy of banks and depositors' fear that provides deposit outflow. Regarding to the current situation, according to official data of the National Bank of Ukraine, the volume of deposits in national currency decreased in March by $2.0 \%$ (YTD $5.7 \%)$. That was due to the reduction account balances of individuals by $4.1 \%$ (YTD 10.1\%) while deposits of entities increased by $0.2 \%$ (since the beginning of the year they fell by $0,6 \%)$. The volume of deposits in foreign currency in the past month fell by $7.4 \%$ (YTD $14.4 \%$ ), including entities by 7.3\% (YTD 10.7\%), individuals by 7.4\% (YTD 15.9\%) [4].

Analysis is further confirmation of the negative situation in the Ukrainian banking sector, which is characterized by a significant outflow of funds of natural persons from the banking sector of Ukraine, which in turn has a negative impact on the resource base of banks in Ukraine. The negative consequences of this situation are difficult to overestimate, because the banks are forced to seek alternative sources of resource support, as well as solve the problem of liquidity. According to the National Bank of Ukraine only in March 2015 the total amount of refinancing is 13,8 bil. UAH., which was granted to 24 banks. Overnight loans totaled 7,7 bil. UAH. and was provided by 14 banks. We analyzed the successful banks to make recommendations on development of deposit policy for banking institutions (Table 1).

Analysis shows that these 5 banking institutions keep 44,26\% retail deposits. These banks have positive reputation, high-qualified staff, wide range of deposit services, actual interest rate, loyal customers base and use high information technologies to support its' clients. The deposit policy of these banks is based on marketing policy- promotion and distribution of deposit policy, banking management - actual conditions and rational agreements, flexibility. In author's opinion, flexibility is one of the main characteristics which banking institutions should use in current economic, political and military situations.

\section{Conclusion}

From our research it could be concluded that the bank's effectiveness on attraction additional funds and ensuring its competitiveness in the market of the banking services largely depend on the introduction of new deposit products.

Thus, the modern domestic banks deposit policy requires continuous improvement. Among the main directions to improve its efficiency are:

- improving the regulatory protection of individuals and entities who held deposit accounts;

- simplifying the functioning of deposit accounts: transfer of funds to deposits, cash and transfers from deposit accounts, use of fixed-term deposits with additional contributions or charges;

- creating favorable conditions for enhancing the use by banks of price and non-price methods in marketing policy, makes it possible to offer wider range of high quality services for individuals and investors, improve service quality, increase the interest of individuals and entities to place their funds on deposit accounts of banking institutions;

- improving the quality of customer service through the use of new information technologies in the banking sector, as well as the advanced training of bank employees.

The strengthening of the resource base and ensuring effective domestic bank deposit policy, the integration of the banking system of Ukraine in the global financial space largely depends on the growth of capital that could be provided with rational deposit policy.

Deposit policy is a system of management solutions, program of actions that contains the activities of the bank in carrying out deposit operations. It plays major role in bank activity and competitiveness.

The optimal ratio between the main components of the resource base, which is the basis of deposits, promotes optimization model resource providing commercial bank. Sufficient resources enable banking institutions to effectively perform its functions and achieve the main goal, which is to profit at the expense of active operations. Thus enough resources in the banking institution will maintain its liquidity and reliability, as well as neutralize certain risks inherent in the banking sector.

Table 1

Deposit policy of Ukrainian banks

\begin{tabular}{|c|c|c|c|c|c|c|c|}
\hline$\#$ & Bank & Payment of interest & $\begin{array}{l}\text { Possibility of early } \\
\text { withdrawal or } \\
\text { recharge }\end{array}$ & $\begin{array}{c}\text { Investment } \\
\text { terms }\end{array}$ & $\begin{array}{c}\text { Annual rate, } \\
\text { for deposits in } \\
\text { UAH, \% }\end{array}$ & $\begin{array}{c}\text { Annual rate, } \\
\text { for deposits in } \\
\text { USD, } \%\end{array}$ & $\begin{array}{l}\text { Bank's part in } \\
\text { the market of } \\
\text { retail deposits }\end{array}$ \\
\hline 1. & "Privatbank" & monthly & recharge & 1-12 months & 24 & 12 & 25,48 \\
\hline 2. & "Oschadbank" & monthly & - & 6-36 months & 21 & 9,5 & 8,66 \\
\hline 3. & "Ukreximbank" & monthly & withdrawal, recharge & 6-12 months & 18,4 & 6,75 & 5,17 \\
\hline 4. & $\begin{array}{l}\text { "Raiffeisen } \\
\text { Bank Aval" }\end{array}$ & $\begin{array}{l}\text { on the day of the } \\
\text { deposit term end }\end{array}$ & withdrawal, recharge & 12 months & 14 & 3 & 3,36 \\
\hline 5. & "Ukrgasbank" & monthly & recharge & 6-12 months & 23 & 11 & 1,62 \\
\hline
\end{tabular}




\section{References}

Alekseev, A. (2012, September 14). Autumn savings: how to preserve and multiply? Mirror of the week. Ukraine, 32. Retrieved from http://zn.ua/ECONOMICS/osennie_sberezheniya_kak_sohranit_i_priumnozhit-108763.html. Barr, Nicholas (2001). The welfare state as piggy bank: Inform., risk, uncertainty, the role of the state: 195-200.

Basic indicators of banks in Ukraine (2015). Retrieved from http://www.bank.gov.ua/control/uk/publish/ article?art_id $=36807 \&$ cat_id $=36798$

Batrakova, L. (2009). The constituent elements of an effective resource policy of commercial banks. Regional Economics, 3: 115-122.

Demirgüç-Kunt, Asli (2006). Determinantes of deposit-insurance adoption and design: 72-73.

Dziubliuk, O. (2008). Optimizing the formation of the resource base of commercial banks. Banking, 5: 38-46.

Information on financial support to banks' liquidity provided by the National bank of Ukraine. Retried from http://www.bank.gov.ua/doccatalog/document?id=16283713

Fursova, V. (2011). Formation of the resource base of commercial banks: current state and prospects of development. Open information and computer integrated technologies, 50: 118-124.

Main trends for monetary market in Ukraine. Retried from http://www.bank.gov.ua/control/uk/publish/ article?art_id $=14716098 \&$ cat_id $=58038$

Shihata, Ibrahim F.I. (2000) The World bank Inspection panel: in practice: 41-45.

Ukrainian index on interest rates for individuals. Retried from http://www.bank.gov.ua/control/uk/index

\section{Надежда БОВА}

\section{РОЛЬ ДЕПОЗИТНОЙ ПОЛИТИКИ ДЛЯ БАНКОВСКИХ УЧРЕЖДЕНИЙ УКРАИНЫ}

Аннотация. Цель данной работы является определение роли депозитной политики для банковских учреждений. Для этого, необходимо обобщить и выделить проблемы депозитной политики Украины, а также найти способы их решения. Депозитная политика тесно взаимосвязана и взаимозависима от экономического спада и имеет влияние на восстановление банковской системы. Адекватный выбор и реализация целей депозитной политики, ее операционной структуры и инструментов определяется степенью развития финансовой инклюзивности, благодаря которой создается клиентооринтований финансовый рынок, обеспечивает доверие населения к депозитным услуг и повышает уровень сбережений, что положительно влияет на финансовую устойчивость банковской системы и экономики в стране в целом. Именно из-за доступности и защищенности депозитных услуг коммерческие банки Украины имеют возможность увеличить свою ресурсную базу за счет привлечения средств населения. Методология. Эта работа основана на синтезе данных для изучения ситуации по привлечению депозитов в банках. Рассмотрены научные и теоретические подходы к разработке управленческих решений по депозитной политике. Работа содержит анализ динамики и текущей ситуации и условий ресурсного потенциала банковских учреждений в Украине. Результаты статьи показывают прямую зависимость между сбережениями, потреблением и депозитной политикой, поэтому каждое банковское учреждение включает в себя механизм банковского управления разработки и реализации депозитной политики. Кроме того, это управление определяет направления депозитной политики в соответствии с условиями мобилизации ресурсов и её банковское применение в активных операциях банка. Полученные результаты подтверждают, что термин "депозитная политика" является слишком сложным, но исследуется во взаимодействии с банковской деятельностью. Термин «депозитная политика» рассматривается в статье с разных точек зрения, используя разные критерии и подходы. Автор объясняет, как депозитная политика влияет на банковскую систему и оказывает влияние на экономический рост в целом. Практическое значение. Исследование создает методологические подходы к измерению эффективности депозитной политики. Кроме того, оно изучает существующие и предлагает новые подходы для повышения эффективности банковского менеджмента. Это дает возможность определить, какие из подходов работают в нестабильной экономической ситуации, а какие нет. Эта статья имеет за цель оценить возможности депозитной политики в балансировании и обеспечения финансовой стабильности банковской системы Украины в период экономического роста и во время финансовой нестабильности. Значение/оригинальность. Несмотря на наличие существенного научного задела в данном направлении, на сегодня в научной литературе нет устоявшегося и комплексного видения относительно необходимой направленности и механизмов влияния депозитной политики на банковскую систему. Это определяет потребность в формализации концептуальных основ и необходимых условий для создания финансовой инклюзивности, углубления научно-методической базы исследования депозитной политики. Эта статья предусматривает мнение автора на определение важной роли депозитной политики для банковских учреждений и национальной экономики в целом. 